\title{
PERHATIAN ORANG TUA DALAM PENDIDIKAN KEAGAMAAN ANAK DI RUMAH HUBUNGANNYA DENGAN PERILAKU MEREKA DI LINGKUNGAN SEKOLAH
}

\author{
Ujang Dedih"), Qiqi Yuliati Zakiyah'), Jeri Oky Melina ${ }^{3)}$, \\ 1) Jurusan Pendidikan Agama Islam, FTK Uin Sunan Gunung Djati Bandung \\ Email: melinaoky2@gmail.com
}

\begin{abstract}
This study aims to determine: (1) student responses to parental attention in children's religious education at home, (2) children's behavior in the school environment and (3) the relationship of student responses to parents' attention in children's religious education at home with their behavior in the school environment. The conduct of behavioral coaching includes politeness and manners, namely how to say and behave well to parents, relatives, neighbors and the community. The method used is descriptive method while the tools and techniques in collecting data are: questionnaires, interviews, observations (observations), literature. The results of the analysis of this study indicate that parents' attention in children's religious education at home includes a high category based on an average score of 4 in the intervals of 3,40 - 4,19. Their behavior in the school environment is categorized as high based on the average score of 4 in the intervals of 3,40 - 4,19. The relationship between the two in the correlation analysis of the degree of relationship between variables $X$ and $Y$ is determined using the product moment correlation formula with a number of correlation coefficients of 0.55 . Based on hypothesis testing using the formula obtained by the calculation hypothesis (6.16)> (7.35), the hypothesis is accepted. The relationship of variable $X$ to $Y$ variable is $60 \%$ while $40 \%$ is influenced by other factors.
\end{abstract}

Keywords:

Attention, Behavior

\begin{abstract}
Abstrak : Penelitian ini bertujuan untuk mengetahui: (1) tanggapan siswa terhadap perhatian orang tua dalam pendidikan keagamaan anak di rumah , (2) perilaku anak di lingkungan sekolah dan (3) hubungan tanggapan siswa terhadap perhatian orang tua dalam pendidikan keagamaan anak di rumah dengan perilaku mereka di lingkungan sekolah. Pelaksanaan pembinaan perilaku mencakup pula kesopanan dan tata krama, yakni cara berkata dan bertingkah laku yang baik kepada orang tua, sanak saudara, tetangga dan masyarakat. Metode yang digunakan adalah metode deskriptif sedangkan alat dan teknik dalam pengumpulan data adalah: angket, wawancara, observasi (pengamatan), studi pustaka. Hasil analisis penelitian ini menunjukkan bahwa perhatian orang tua dalam pendidikan keagamaan anak di rumah termasuk kategori tinggi berdasarkan skor rata-rata 4 yang berada pada interval 3,40 - 4,19. Perilaku mereka di lingkungan sekolah berkategori tinggi berdasarkan skor rata-rata 4 yang berada pada interval 3,40 - 4,19. Hubungan keterkaitan keduanya dalam analisis korelasi derajat hubungan variabel $\mathrm{X}$ dan variabel Y ditentukan menggunakan rumus korelasi product moment dengan angka koefisien korelasi 0,55 . Berdasarkan pengujian hipotesis dengan menggunakan rumus di peroleh hipotesis hitung $(6,16)>$ $(7,35)$ maka hipotesis diterima. Hubungan variabel X terhadap variable $\mathrm{Y}$ sebesar $60 \%$ sedangkan $40 \%$ lagi dipengaruhi oleh faktor lain.
\end{abstract}

Kata kunci: Perhatian, Perilaku

\section{PENDAHULUAN}

Setiap anak membutuhkan perhatian dan kasih sayang orang tua sehingga orang tua memiliki tanggung jawab yang besar atas perkembangan kehidupan anaknya. Orang tua merupakan pendidik pertama dan utama bagi anak-anaknya. Dikatakan sebagai 
pendidik pertama karena di keluarga seorang anak mendapatkan pendidikan untuk pertama kalinya, sebelum ia mendapat pendidikan yang lain, sedangkan sebagai pendidikan utama karena pendidikan dari keluarga mempunyai pengaruh yang sangat besar bagi kehidupan anak kelak di kemudian hari (Uhbiyati, 2003:176).

Perhatian orang tua merupakan salah satu faktor terpenting dalam perkembangan perilaku anak. menurut (Purwanto, 2009:90) mengatakan bahwa pendidikan orang tua terhadap anak-anaknya adalah pendidikan yang didasarkan pada rasa kasih sayang terhadap anak-anak, dan yang diterimanya dari kodrat. Orang tua adalah pendidik sejati, pendidik karena kodratnya. Oleh karena itu, kasih sayang orang tua terhadap anak-anak hendaklah kasih sayang yang sejati pula. Berarti pendidik atau orang tua mengutamakan kepentingan dan kebutuhan anak-anak, dengan mengesampingkan keinginan dan kesenangan sendiri. Dalam hal ini hendaknya kita harus ingat pula bahwa pendidikan berdasarkan kasih sayang saja kadang-kadang mendatangkan bahaya. Kasih sayang harus dijaga jangan sampai berubah, menjadi memanjakan anak.

Keluarga adalah fondasi pengembangan karakter (moral atau akhlak) dan intelektual. Dengan demikian, baik atau tidaknya karakter anak-anak tergantung pada seberapa baik karakter bagaimana upaya orang tua dalam membimbing dan mengarahkan mereka. Orang tua yang memiliki karakter yang baik dan mampu menerapkan pada anak-anaknya tentu akan membuat anak-anaknya memiliki karakter yang baik.

Berdasarkan observasi pendahuluan yang dilakukan oleh penulis, di SMP Muhammadiyah 10 Bandung, yang menjadi masalah diantaranya anak tidak sadar bahwa mereka dicintai orang tuanya, maka siswa menjadi acuh tak acuh. Meskipun demikian orang tua tetap harus lebih memperhatikan anaknya agar anaknya selalu merasa diinginkan kehadirannya.

Oleh karena itu, berdasarkan hasil analisis penelitian terhadap perhatian orang tua dalam pendidikan keagamaan anak di rumah, maka perlu diterapkan suatu strategi dari orang tua yang dapat membantu siswa untuk menyadari bahwa mereka dicintai keluarganya.

Penulis, melakukan penelitian yang berjudul: " Perhatian Orang Tua dalam Pendidikan Keagamaan Anak di Rumah Hubungannya dengan Perilaku Mereka di Lingkungan Sekolah”.

Berdasarkan pemaparan yang telah diuraikan sebelumnya, dalam penelitian ini dapat diajukan permasalahan yaitu 1) Bagaimana tanggapan siswa terhadap perhatian orang tua dalam pendidikan keagamaan anak di rumah ?, 2)Bagaimana perilaku anak di lingkungan sekolah?, 3)Bagaimana hubungan tanggapan siswa terhadap perhatian orang tua dalam pendidikan keagamaan anak di rumah dengan perilaku mereka di lingkungan sekolah?.

Tujuan yang ingin dicapai dalam penelitian ini untuk Mengetahui tanggapan siswa terhadap perhatian orang tua dalam pendidikan keagamaan anak di rumah, Mengetahui perilaku anak di lingkungan sekolah, Mengetahui hubungan tanggapan 
siswa terhadap perhatian orang tua dalam pendidikan keagamaan anak di rumah dengan perilaku mereka di lingkungan sekolah.

\section{METODOLOGI PENELITIAN}

Metode yang digunakan dalam penelitian ini adalah deskriptif dengan teknik analisi korelasi, menurut Sumanto yang dikutif oleh (Priatna, 2007) metode deskriptif adalah penelitian yang diupayakan

untuk mengamati permasalahan secara sistematis dan akurat mengenai fakta-fakta dan sifat-sifat objek tertentu. Metode ini berusaha menggambarkan dan menginterpretasikan apa yang ada, mengenai kondisi atau hubungan yang ada, pendapat yang sedang tumbuh, proses yang sedang berlangsung, akibat atau efek yang terjadi, atau kecenderungan yang tengah berkembang. Untuk penarikan kesimpulan digunakan teknik korelasi, yaitu teknik yang membahas tentang derajat hubungan variable-variabel (Sudjana, 2005).

Deskripsi data yang akan disajikan dari hasil penelitian ini adalah untuk memberikan gambaran secara umum mengenai penyebaran data yang diperoleh di lapangan. Data yang disajikan berupa data mentah yang diolah menggunakan teknik statistik deskripsi. Adapun yang disajikan dalam deskripsi data ini adalah berupa distribusi frekuensi yang disajikan perindikator beserta persentase frekuensi dan perolehan skor.

Berdasarkan judul dan perumusan masalah dimana penelitian ini terdiri dari dua variable bebas dan satu variable terikat, yaitu meliputi data mengenai perhatian orang tua dalam pendidikan keagamaan anak di rumah (X) dan perilaku mereka di lingkungan sekolah (Y). dikarenakan penelitian ini dilakukan pada kelas VII, VIII, IX SMP Muhammadiyah 10 Bandung yang berjumlah 399 siswa maka subjek yang diambil adalah $10 \%$ dari 399 siswa. Maka siswa yang dipilih menjadi sampel dalam penelitian ini adalah 40 orang. Pada penelitian ini data diperoleh dengan mengantarkan langsung kuesioner kepada responden yang berada di SMP Muhammadiyah 10 Bandung, yang menjadi sampel dalam penelitian ini kelas VII, VIII, IX , dengan menyebarkan 52 kuesioner. Setiap kuesioner diberikan kepada responden dan diharapkan agar responden dapat mengisi pernyataan-pernyataan yang diajukan pada kuesioner sesuai dengan keadaan sebenarnya. Dari 52 kuesioner yang disebarkan kepada siswa kelas VII, VIII, IX, dapat diolah menjadi data yang berguna bagi kelanjutan penelitian.

Data yang ditabulasi adalah sesuai jawaban responden atas pernyataan yang ada dalam kuesioner. Dalam pengolahan data, penyataan-pernyataan tersebut diberi skor yang menunjukkan tingkat setujunya responden dalam memilih jawaban dengan diberi skor dari 1 sampai 5. Pernyataan-pernyataan tersebut berhubungan antara perhatian orang tua dalam pendidikan keagamaan anak di rumah dengan perilaku mereka di lingkungan sekolah. Data hasil tabulasi diolah menggunakan teknik analisi korelasi yang menghasilkan deskripsi statistik

Pada penelitian ini terdapat dua variabel yaitu variabel bebas dan variabel terikat. Variabel bebas merupakan variabel yang mempengaruhi variabel terikat. Variabel terikat adalah variabel yang dipengaruhi oleh variable bebas. Pada penelitian ini 
perhatian orang tua dalam pendidikan keagamaan anak di rumah sebagai variabel bebas (X) dan perilaku mereka di lingkungan sekolah sebagai variabel terikat (Y).

Teknik pengumpulan data dapat dilakukan dalam berbagai setting berbagai sumber dan berbagai cara. Teknik pengumpulan data yang dilakukan dalam penelitian ini penulis menggunakan beberapa teknik penelitian, dengan teknik pengumpulan data pokok berupa angket, juga teknik pengumpulan data pelengkap berupa observasi dan wawancara,

Teknik analisis data yang digunakan untuk mengolah data hasil penelitian ini menggunakan teknik statistik karena data yang diambil merupakan data kuantitatif, dan analisisnya adalah teknik analisis korelasi. Sebelum melakukan analisis data dilakukan uji prasyarat analisis meliputi: uji normalitas dan uji linieritas.

Uji normalitas digunakan untuk menentukan apakah data berdistribusi normal atau tidak. Untuk menguji linearitas menggunakan analisis regresi sederhana, karena variabelnya terdiri dari 2 prediktor yaitu X1 dan X2.

Uji linieritas Menghitung harga $\mathrm{F}$ tabel dengan menggunakan taraf signifikansi $1 \%$ serta dengan derajat kebebasan $(\mathrm{dbtc} / \mathrm{dbkk}=4 / 36)$ kemudian dilihat pada $\mathrm{F}$ tabel, yaitu :

F $0,99(4 / 36)=9488$.

Nilai $\mathrm{F}$ hitung lebih kecil dari $\mathrm{F}$ tabelnya atau $\mathrm{F}$ hitung $=4500<\mathrm{F}$ tabel $=9488$, maka dapat disimpulkan bahwa regresi $\mathrm{Y}$ atas $\mathrm{X}$ menunjukkan kelinieran.

Berdasarkan hasil perhitungan diperoleh nilai Chi Kuadrat (X2) hitung sebesar 1,03 dan Chi Kuadrat (X2) tabel sebesar 2,97. Ternyata X2 hitung (1,03) lebih kecil dari X2 tabelnya $(2,97)$. Maka dapat disimpulkan bahwa data variabel X (perhatian orang tua dalam pendidikan keagamaan anak di rumah) berdistribusi normal.

\section{HASIL PENELITIAN DAN PEMBAHASAN}

Tanggapan merupakan fungsi jiwa yang pokok setelah ada pertemuan, jika proses pengamatan telah terhenti maka yang tinggal kesan-kesannya. Abu Ahmadi (2003:64) mendefinisikan bahwa tanggapan adalah gambaran ingatan dari pengamatan, yang telah diamati tidak lagi berada dalam ruang dan waktu pengamatan, yang ada kesan-kesannya saja. Sementara itu Kartini Kartono (2010:57) mengatakan tanggapan ada kesan-kesan yang dialami jika pengarang sudah tidak ada.

Dilihat dari pengertian di atas menghasilkan dua kemungkinan yaitu:

1. Tanggapan positif yaitu tanggapan yang didasari dengan perasaan senang karena diiringi oleh bayangan pengiring positif yang sesuai dengan objeknya, seperti mendekati, menyayangi, menyukai dan lain-lain.

2. Tanggapan negatif yaitu tanggapan yang didasari dengan perasaan tidak senang karena diiringi oleh bayangan negatif yang tidak sesuai dengan objeknya, seperti menjauhi, tidak menyenangi, membenci, dan tidak menyukai dan lain-lain.

Agus Sujanto (2005:31) mengemukakan tanggapan sebagai gambaran pengamatan yang tinggal dikesadaran kita sesudah mengamati. Sedangkan Ngalim Purwanto (2009:36) mengemukakan bahwa tanggapan adalah suatu daya jiwa untuk 
memasukkan kesan-kesan dari luar dengan menggunakan alat indera. Sejalan dengan ini Sadirman A.M. (2004:43) berpendapat bahwa tanggapan adalah gambaran yang tinggal dalam ingatan setelah orang melakukan pengamatan.

Kartini Kartono (2010:58) mengemukakan tanggapan disebut latent (tersembunyi, belum terungkap), apabila tanggapan tersebut ada di bawah sadar, atau tidak kita sadari. Sedang tanggapan disebut aktual, apabila tanggapan tersebut kita sadari. Pada umumnya, kesan atau gambar pengamatan itu lebih jelas, lebih jernih dan lebih lengkap daripada gambar tanggapan. Menurut Wasty Soemanto (2012:25), tanggapan adalah bayangan yang menjadi kesan yang dihasilkan dari pengamatan. Kesan tersebut menjadi isi kesadaran yang dapat dikembangkan dalam hubungannya dengan konteks pengalaman waktu sekarang serta antisipasi keadaan untuk masa yang akan datang dalam ingatan setelah kita melakukan pengamatan (Bigot dkk.,2005:72). Akan tetapi definisi ini kurang menggambarkan materinya, sebab hanya menunjuk kepada sebagian saja dari tanggapan itu.

Berdasarkan beberapa definisi di atas, tanggapan adalah salah satu fungsi kejiwaan yang dapat diperoleh individu setelah proses pengamatan selesai. Sebab, dalam proses pengamatan terdapat gambaran pengamatan dalam jiwa individu. Sementara gambaran tersebut tidak langsung hilang setelah pengamatan selesai. Setiap individu mempunyai kemampuan membayangkan atau menggambarkan kembali kesan-kesan yang telah diamati tersebut, dalam hal ini adalah kesan-kesan yang tinggal dalam ingatan siswa setelah melakukan pengamatan terhadap kompetensi profesional guru PAI dalam melaksanakan proses pembelajaran. Tanggapan ini bermula dari adanya suatu tindakan pengamatan yang menghasilkan suatu kesan sehingga menjadi kesadaran yang dapat dikembangkan pada masa sekarang atau menjadi antisipasi pada masa yang akan datang. Pengamatan merupakan modal dasar dari tanggapan, sedangkan modal dari pengamatan adalah alat indera yang meliputi penglihatan dan penginderaan.

Tanggapan sering diistilahkan sebagai bayangan seseorang terhadap suatu hal. Bayangan merupakan proses pengamatan dimana terjadilah situasi dan kondisi. Dalam proses pengamatan itulah terjadi gambaran di dalam jiwa individu. Hasil pengamatan itu mengalami proses selanjutnya, ia tidak akan hilang begitu saja tetapi tersimpan dalam jiwa individu dan membayangkan kembali atau mengungkapkan gambaran-gambaran yang terjadi disaat melakukan pengamatan, maka didalam menanggapi atau membayangkan adalah representasi. Pada umumnya gambaran yang terjadi pada pengamatan lebih jelas jika dibandingkan dengan gambaran tanggapan.

Adapun perbedaan antara pengamatan dan tanggapan yaitu:

a. Pengamatan terikat pada tempat dan waktu, sedangkan tanggapan tidak terikat pada waktu dan tempat.

b. Tanggapan tidak memerlukan adanya obyek atau sasaran sehingga gambarannya tidak mendetail dan kabur.

c. Pengamatan memerlukan adanya obyek sehingga gambarannya sempurna dan detail. 
d. Pengamatan memerlukan perangsang, sedangkan tanggapan tidak perlu perangsang.

e. Pengamatan merupakan fungsi yang bersifat sensorik sedangkan tanggapan bersifat imajiner.

f. Pengamatan berlangsung selama stimulus itu bekerja dan tertuju kepadanya, sedangkan tanggapan selama perhatian tertuju kepada bayangan tersebut. seperti yang dikemukakan diatas bahwa tanggapan itu terbentuk disaat proses membayangkan menjadi pusat perhatian.

Perhatian akan timbul ketika alat-alat indera terkena rangsangan yang sadar individu bersangkutan akan mengkosentrasikan diri dengan alat indera yang terkena rangsangan tersebut.

Kartini Kartono (2010:111) mengemukakan perhatian merupakan reaksi umum dari organisme dan kesadaran, yang menyebabkan bertambahnya aktivitas, daya konsentrasi, dan pembatasan kesadaran terhadap satu objek. Menurut Abu Ahmadi (2003:145) perhatian yaitu keaktifan jiwa yang diarahkan kepada sesuatu obyek baik di dalam maupun di luar dirinya. Menurut Sumadi Suryabrata (2013:13) mengatakan "perhatian", tidaklah selalu digunakan dalam arti yang sama. Beberapa contoh dapat menjelaskan hal ini:

a. Dia sedang memperhatikan contoh yang diberikan oleh gurunya.

b. Dengan penuh perhatian dia mengikuti kuliah yang diberikan oleh dosen yang baru itu.

Kedua contoh di atas mempergunakan kata perhatian. Arti kata tersebut, baik di masyarakat dalam kehidupan sehari-hari maupun dalam bidang psikologi kira-kira sama. Karena itulah maka definisi mengenai perhatian itu yang diberikan oleh ahli psikologi ada dua macam, yaitu kalau diambil intinya saja dapat dirumuskan sebagai berikut:

a. Perhatian adalah pemusatan tenaga psikis tertuju kepada suatu objek.

b. Perhatian adalah banyak sedikitnya kesadaran yang menyertai suatu aktivitas yang dilakukan.

Pengertian perhatian menurut Wasty Soemanto (2012:32) ada dua macam, yaitu:

1) Perhatian adalah pemusatan tenaga atau kekuatan jiwa tertuju kepada sesuatu obyek.

2) Perhatian adalah pendayagunaan kesadaran untuk mnyertai suatu aktivitas.

Kutipan di atas, dapat disimpulkan bahwa yang dimaksud perhatian adalah pemusatan jiwa yang ditunjukkan kepada sesuatu obyek atau pendayagunaan kesadaran yang menimbulkan betambahnya kegiatan.

Perhatian dalam pendidikan sangat dibutuhkan. Karena tanpa adanya perhatian baik dari diri anak itu sendiri ataupun dari luar diri anak, proses belajar tidak akan berjalan dengan lancar dan bahkan tidak akan berhasil. Dalam hal ini, Al-Ghazali berpendapat tentang perhatian yang dikutip oleh Slameto (2005:56) yaitu: 
Perhatian adalah keaktifan jiwa yang dipertinggi, jiwa itupun semata-mata tertuju kepada sesuatu obyek. Untuk dapat menjamin perilaku siswa yang baik, maka siswa harus mempunyai perhatian dari orang tua.

Kutipan di atas, dapat disimpulkan bahwa apabila siswa tidak mempunyai perhatian terhadap dirinya maka akan timbul rasa malas, bosan dan acuh tak acuh. Selain seorang anak harus mempunyai perhatian yang tumbuh dari dirinya sendiri, anak juga memerlukan perhatian dari orang tua, karena dengan adanya perhatian dari orang tua terhadap anaknya, maka anak akan merasa diperhatikan oleh kedua orang tuanya dan anak akan lebih baik perilakunya baik di lingkungan keluarga maupun lingkungan sekolah. Kurangnya perhatian orang tua terhadap anak akan berakibat buruk pada perilakunya.

Kutipan di atas, dapat diambil kesimpulan bahwa perhatian merupakan salah satu faktor yang paling penting dan bahkan dapat dikatakan sebagai faktor yang paling dominan dalam proses pendidikan. oleh karena itu sebagai orang tua harus dapat memberikan perhatian, sebab kurangnya perhatian terhadap pendidikan anak, proses pendidikan anak akan terbengkalai dan akhirnya pendidikan anak kurang berhasil dengan baik.

Perhatian adalah kegiatan yang dilakukan seseorang dalam hubungannya dengan pemikiran rangsangan yang datang dari lingkungannya (Slameto, 1995:105). Dari kutipan di atas, sudah jelas bahwa perhatian yang ditimbulkan seseorang dengan yang lainnya tidak sama. Oleh karena itu untuk dapat membedakan perhatian, maka akan dijelaskan beberapa jenis perhatian, yaitu:

Sumadi Suryabrata (2013:14) mengemukakan bahwa ada jenis-jenis perhatian yang pada pokok-pokoknya, yaitu:

a) Jenis-jenis perhatian atas dasar intensitasnya, yaitu banyak sedikitnya kesadaran yang menyertai sesuatu aktivitas atau pengalaman batin, maka dibedakan menjadi:

1) Perhatian Intensif; yaitu perhatian yang banyak dikuatkan oleh banyaknya rangsangan atau keadaan yang menyertai aktivitas atau pengalaman batin.

2) Perhatian tidak intensif; yaitu perhatian yang kurang diperkuat oleh rangsang atau beberapa keadaan yang menyertai aktivitas atau pengalaman batin.

b) Jenis-jenis perhatian atas dasar cara timbulnya, perhatian dibedakan menjadi:

1) Perhatian Spontan; yaitu perhatian yang tidak disengaja atau tidak sekehendak subyek.

2) Perhatian Refleksif; yaitu perhatian yang disengaja atau sekehendak subyek.

c) Jenis-jenis perhatian atas dasar luasnya objek, perhatian dibedakan menjadi:

1) Perhatian Terpusat; yaitu perhatian yang tertuju kepada lingkungan obyek yang sangat terbatas, perhatian ini sering pula disebut sebagai perhatian konsentratif. Jadi orang yang mengadakan konsentrasi pikiran berarti berpikir dengan perhatian terpusat.

2) Perhatian Terpencar; yaitu perhatian yang pada suatu saat tertuju pada lingkup obyek yang luas atau tertuju kepada bermacam-macam obyek. Perhatian yang demikian dapat dilakukan seorang guru di kelas yang pada suatu saat ia harus 
menunjukkan perhatian kepada tujuan pelajaran, materi pelajaran, buku pelajaran, alat pelajaran, metode belajar mengajar, lingkungan fisik kelas, dan tingkah laku anak didik yang cukup banyak jumlahnya.

Abu Ahmadi (2003:148) mengemukakan jenis-jenis perhatian yaitu:

1) Perhatian spontan dan disengaja

Perhatian spontan, disebut pula perhatian asli atau perhatian langsung, ialah perhatian yang timbul dengan sendirinya oleh karena tertarik pada sesuatu dan tidak didorong oleh kemauan karena adanya tujuan tertentu. Perhatian dengan sengaja ditujukam kepada suatu obyek, misalnya anak mendapat tugas dari orang tuanya untuk belajar, yakni belajar di sekolah. Didorong oleh tugas dari orang tua dan pelajaran cukup besar. Mereka belajar rajin, tekun dan penuh tanggung jawab. Mereka menyadari bahwa berhasil atau tidaknya ujian, akan berpengaruh kepada dirinya dan akan mempunyai arti besar bagi hidupnya.

2) Perhatian statis dan dinamis

Perhatian statis ialah perhatian yang tetap terhadap sesuatu. Ada orang yang dapat mencurahkan perhatiannya kepada sesuatu seolah-olah tidak berkurang kekuatannya. Dengan perhatian yang tetap itu maka dalam waktu yang agak lama orang dapat melakukan sesuatu dengan perhatian yang kuat. Misalnya seorang anak memperhatikan sekali pelajaran seni suara. Agaknya pelajaran ini cocok untuknya. Dalam waktu agak lama perhatiannya terhadap suasana musik atau seni masih cukup kuat, tidak mudah berpindah ke obyek yang lain. Perhatian dinamis ialah perhatian yang mudah berubah-rubah, mudah bergerak, mudah berpindah dari obyek yang satu ke yang lain. Supaya perhatian kita terhadap sesuatu tetap kuat, maka tiap-tiap kali perlu diberi perangsang baru.

3) Perhatian konsentratif dan distributive

Perhatian konsentratif (perhatian memusat), yakni perhatian yang hanya ditujukan kepada satu obyek (masalah) tertentu. Mislanya: seseorang sedang memecahkan soal aljabar yang sangat sulit. Saat itu jiwa dipusatkan pada soal-soal aljabar, jiwa dan perhatian tidak bercabang. Sifat konsentratif itu umumnya agak tetap kukuh dan kuat, tidak gampang memindahkan perhatiannya ke obyek yang lain.

Perhatian distributive (perhatian terbagi-bagi). Dengan sifat distributive ini orang dapat membagi perhatiannya kepada beberapa arah dengan sekali jalan/dalam waktu yang bersamaan. Misalnya: guru sedang mengajar, sopir sedang mengemudi mobil, polisi lalu lintas bertugas di tengah-tengah jalan yang ramai.

4) Perhatian sempit dan luas

Perhatian sempit ialah orang yang mempunyai perhatian sempit dengan mudah dapat memusatkan perhatiannya kepada suatu obyek yang terbatas, sekalipun ia berada dalam lingkungan ramai. Dan lagi orang semacam itu juga tidak mudah memindahkan perhatiannya ke obyek lain, jiwanya tidak mudah tergoda oleh keadaan sekelilingnya.

Perhatian luas ialah orang yang mempunyai perhatian luas mudah sekali tertarik oleh kejadian-kejadian sekelilingnya; perhatiannya tidak dapat mengarah kepada hal-hal tertentu, mudah terangsang dan mudah mencurahkan jiwanya kepada hal-hal yang baru. 


\section{5) Perhatian fiktif dan fluktuatif}

Perhatian fiktif (perhatian melekat), yakni perhatian yang mudah dipusatkan pada suatu hal dan boleh dikatakan bahwa perhatiannya dapat melekat lama pada obyeknya. Orang yang bertype perhatian melekat biasanya teliti sekali dalam mengamati sesuatu, bagian-bagiannya dapat ditangkap, dan apa yang dilihatnya dapat diuraikan secara obyektif.

Perhatian fluktuatif (bergelombang). Orang yang mempunyai type ini pada umumnya dapat memperhatikan bermacam-macam hal sekaligus, tetapi kebanyakan tidak seksama. Perhatiannya sangat subyektif, sehingga yang melekat padanya hanyalah hal-hal yang dirasa penting bagi dirinya.

Kutipan di atas, dapatlah diketahui bahwa perhatian itu mempunyai beberapa jenis atau dengan kata lain perhatian itu macam-macam. Misalnya perhatian di dalam proses belajar mengajar, para murid dalam menerima materi pelajaran jarang sekali mengunakan perhatian spontan atau perhatian tak sengaja, tapi kebanyakan para siswa menggunakan perhatian yang disengaja. Karena itu sebagai guru harus selalu berusaha menarik perhatian para siswanya.

Salah satu usaha dalam memberikan perhatian terhadap anak adalah dengan cara memberikan rangsangan atau stimulus yang dapat menarik perhatian anak. Adapun cara memberikan perhatian dalam pendidikan anak adalah dengan cara memberikan perhatian dalam bimbingan belajar yang dilakukan di rumah. Berdasarkan hal ini Sofyan Sauri (2006:7) mengemukakan sebagai berikut:

Ada bermacam-macam kegiatan bimbingan orang tua kepada anaknya antara lain: a) Memberikan contoh yang baik; b) Pembiasaan; c) Membuat suasana keagamaan; d) Membimbing dengan bacaan-bacaan keagamaan; e) Melibatkan anak dalam kegiatan keagamaan. Kutipan di atas, dapat dijelaskan bahwa salah satu indikator perhatian orang tua terhadap pendidikan keagamaan anaknya adalah adanya bimbingan belajar di rumah. Untuk indikator perhatian akan dijelaskan dari kegiatan bimbingan belajar. Di antaranya yaitu:

a. Memberikan contoh yang baik

Memberikan contoh yang baik sejatinya kewajiban orang tua sehingga anaknya dapat menjadi anak yang sholeh dan sholehah. Sebagai seorang muslim, kita tahu bahwa anak merupakan titipan Allah SWT. Keutamaan seorang ibu yaitu menginginkan anak yang sholeh dan sholehah, maka orang tua seharusnya berkaca pada diri sendiri apakah dirinya sudah menjadi seorang muslim yang taat pada ajaran agama. Orang tua yang rajin ibadah akan lebih mudah menyuruh anaknya beribadah karena anak sudah mendapatkan contoh dari orang tuanya. Sosok muslim yang baik tidak hanya pada masalah ibadah juga namun pada perilaku atau akhlak yang baik.

\section{b. Pembiasaan}

Pembiasaan merupakan upaya praktis dalam pembinaan dan pembentukan anak. Upaya ini dilakukan mengingat manusia mempunyai sifat lupa dan lemah. Seperti dikutif M. Mujib merumuskan tiga asas pokok metode: 1) Adanya relevansi dengan kecenderungan dan watak anak baik aspek intelegensi, sosial, ekonomi dan status 
keberadaan orang tuanya. 2) Memelihara prinsip umum. Diantaranya, berangsur-angsur dari yang mudah menuju yang sulit, dari yang terperinci ke yang terstruktur, dari yang konkret ke yang abstrak, dari yang ilmiah ke yang filosofis, 3) Memperhatikan perbedaan individual. Misalnya nilai keimanan tidak begitu saja hadir dalam jiwa seseorang, tetapi ia perlu ditanamkan, dipupuk, diarahkan agar menjadi miliknya, menjadi motivasi, semangat dan control terhadap pola tingkah laku.

Metode ini dimaksudkan bahwa seorang ibu harus membiasakan dengan niat dan aktivitas-aktivitas yang baik. Ia mengerjakan pekerjaannya dengan membiasakan tepat waktu, disiplin, bekerja dengan ikhlas, membiasakan memulai pekerjaan dengan menyebut nama Allah, membiasakan untuk bangun malam, membiasakan untuk ramah, sopan, dan santun, membiasakan untuk melakukan yang terbaik dalam kehidupannya. Kebiasaan-kebiasaan baik ini memiliki pengaruh yang positif bagi pendidikan anak dalam suatu keluarga.

Aspek pembinaan nilai-nilai agama dalam keluarga Nampak pula dalam proses pembiasaan melaksanakan shalat yang ditanamkan orang tua sejak anak berusia dini melalui proses identifikasi. Di sini orang tua memperlihatkan bagaimana mereka melaksanakan shalat di rumah. Ayah sebagai imam dimakmumi dan diamini oleh istri dan anak-anak merupakan proses pendidikan yang sangat penting. Anak melihat secara langsung bagaimana salat dilakukan dan perilaku apa yang harus dilakukan pada saat salat. Apa yang dilakukan orang tua akan langsung ditiru anak melalui proses identifikasi.

Kedudukan bapak sebagai imam tidak bisa digantikan oleh ibu, dan urusan saf bagi anak laki-laki dan perempuan yang berbeda, merupakan pengenalan anak terhadap dirinya yang menuntut pemahaman dan tanggung jawab. Melalui proses ini, anak alakilaki disadarkan jati dirinya sebagai laki-laki yang menuntut atribut, perilaku dan perlakuan yang berbeda dengan anak perempuan. Ajakan orang tua untuk salat berjamaah dimasjid merupakan metode yang sangat penting sebagai upaya pengenalan lingkungan keagamaan dan masyarakat kepada anak. Anak diajak bersosialisasi langsung melalui lingkungan yang religious. Di masjid anak melihat orang melaksanakan salat dan menirunya, mendengar orang membaca kalimat-kalimat thayyibah melalui bacaan Al Quran atau puji-pujian. Anak dapat menghafal apa yang sering dibaca orang di masjid dengan tidak terasa dan disadari oleh anak, tetapi dapat memberikan makna tersendiri bagi anak.

Dalam pelaksanaan salat, baik di rumah maupun di masjid dapat dipandang sebagai metode yang membawa anak kepada kebiasaan tertentu yang melekat pada dirinya. Proses pembiasaan yang terus menerus merupakan metode yanh sangat efektif dalam pembinaan anak dalam keluarga. Tafsir (2002:168) menyebutkan bahwa metode pembiasaan pada dasarnya mempengaruhi anak membiasakan perilaku tertentu. Pembiasaan pada dasarnya berjalan bersama bersama metode keteladanan, sebab kebiasaan itu dicontohkan.

Metode keteladanan pada anak merupakan aplikasi dari proses identifikasi yang sedang terjadi pada dirinya, tapi keteladanan memiliki kecenderungan positif, yaitu apa 
yang harus ditiru anak adalah perilaku yang baik. Untuk ini Al-Ghozali (dalam Ulwan) menyatakan bahwa :"Seorang anak merupakan amanat di sisi orang tuanya; hatinya suci dan bening. Jika ia dibiasakan dengan kebaikan dan diajarkan kepada sifat baik ini, ia akan tumbuh dan bahagia di dunia dan akhirat. Sebaliknya jika ia dibiasakan dengan kejahatan ia akan celaka dan menderita.

Dalam pembinaan dasar-dasar nilai dalam agama keluarga nampak pula digunakannya dialog sebagai metode pendidikan. perilaku orang tua dalam kmunikasi dengan anak menggambarkan suasana dialogis yang bermuatan pendidikan. anak diajak berbicara, berpikir dan memutuskan sesuatu masalah merupakan bagian dari proses pembinaan.

Ungkapan orang tua yang terbuka melalui pernyataan atau jawaban dari pertanyaan anak menggambarkan suatu komunikasi dua arah yang memiliki muatan pendidikan. Dialog dipandang sebagai metode pendidikan keluarga ternyata memerlukan adanya keterbukaan, baik dari orang tua maupun anak. Muatan pendidikan nampak dari adanya pengaruh yang disengaja oleh orang tua melalui dialog yang terjadi, sehingga pada ujungnya melahirkan suatu kesiapan anak untuk berubah dari suatu keadaan kepada keadaan lain yang lebih baik. Sehingga dialog memiliki daya pengaruh yang kuat terhadap perubahan pada sikap anak.

Dialog sebagai metode pendidikan telah diakui oleh para ahli pendidikan, khususnya pendidikan Islam. Dalam dialog, orang tua berperan sebagai pengendali suasana yang tidak hanya ditampilkan dalam kata-kata, tetapi diperkuat dengan isyarat yang mempercepat penerapan makna pendidikan. dialog yang menurut Nahlawi (2002:169) disebut hiwar memiliki dampak psikologis yang amat kuat, yakni mendorong anak untuk bertanya, sehingga pendidikan berjalan dengan gairah dan lebih berpengaruh terhadap jiwa mereka. Bahkan Soelaeman (2004:169) menyebutkan bahwa dialog yang memikat cenderung untuk menimbulkan rasa senang bagi orang yang bersangkutan, dengan demikian dapat menimbulkan situasi yang dihayati secara menyenangkan. Di sini anak diharapkan memulai kehidupan kanak-kanaknya dalam lingkungan sosial yang menonjolkan sisi keagamaan, sehingga dapat memberikan dasar kepada anak untuk menghadapi pengalaman lainnya yang akan dihadapinya nanti.

c. Membuat suasana keagamaan

W.J.S Poerwadarminata mengemukakan bahwa:"keagamaan adalah sifat yang terdapat dalam agama; segala sesuatu mengenai agama”. Keagamaan adalah merupakan sikap yang tumbuh atau dimiliki seseorang dan dengan sendirinya akan mewarnai sikap dan tindakan dalam kehidupan sehari-hari. Bentuk sikap dan tindakan yang dimaksudkan yakni yang sesuai dengan ajaran agama, yang dalam hal ini ajaran islam. Keagamaan adalah usaha yang dilakukan seseorang atau kelompok yang dilaksanakan secara terus-menerus. Dikarenakan dalam hal ini ialah yang berhubungan dengan agama islam, maka kegiatan keagamaan di sini yang ada hubungannya dengan pelaksanaan nilai-nilai agama islam itu sendiri, misalnya ceramah keagamaan, shalat berjamaah, shalat sunnat rawatib, tadarus Al Quran dan lain sebagainya. Dari beberapa pengertian yang disebut di atas, maka dalam hal ini perlu penulis tekankan, bahwa yang dimaksud 
dengan kegiatan keagamaan di sini ialah segala bentuk kegiatan yang terencana dan terkendali berhubungan dengan usaha untuk menanamkan bahkan menyebarluaskan nilai-nilai keagamaan dalam tahap pelaksanaannya dapat dilakukan oleh orang perorang atau kelompok. Dengan usaha yang terencana dan terkendali di dalam menanamkan dan menyebarluaskan nilai-nilai keagamaan tersebut diharapkan akan mencapai tujuan dari usaha itu sendiri, yang dalam hal ini penanaman nilai-nilai keagamaan.

\section{d. Membimbing dengan bacaan-bacaan keagamaan}

Penanaman nilai-nilai pendidikan bagi anak dalam keluarga dengan banyak mengucapkan kalimat-kalimat thayibah. Lisan yang basah karena menyebut nama-nama Allah yang agung akan menjadikan seseorang tenang hatinya. Kalimat thayibah yang dapat dibiasakan oleh anak, baik pada waktu setelah salat maupun dalam kondisi tertentu, memberikan nilai yang bermakna bagi anak.

Kalimat-kalimat thayibah adalah kalimat yang mengandung makna mengagungkan, menyucikan, dan mengesakan Allah swt. Dibuktikan oleh ibu dan ayah dalam membesarkan anaknya dalam kandungan. Suami dan istri harus menjaga jalinan kasih sayang ini sehingga anak dalam kandungan dapat merasakannya. Kasih sayang suami terhadap istrinya yang sedang mengandung harus terpancar dalam sikap, perbuatan dan perkataan. Begitu pula ibu yang sedang mengandung anaknya senantiasa memohon kepada Allah agar senantiasa memberikan kasih sayang kepada janinnya. Kondisi keluarga akan damai, tenang, tenteram dan diselimuti kebahagiaan karena keluarga tersebut mewarnai kehidupan keluarganya dengan kasih sayang. Langsung maupun tidak langsung kondisi seperti ini akan melahirkan suasana edukatif bagi yang sedang dikandung.

e. Melibatkan anak dalam kegiatan keagamaan

Pendidikan bukan hanya suatu proses transformasi informasi, melainkan suatu upaya penataan lingkungan yang memberikan pengaruh terhadap suatu perilaku yang diharapkan. Karena itu, pendidikan memerlukan penataan lingkungan baik fisik, psikologis, maupun sosial yang dapat melahirkan suatu situasi yang layak terjadinya suatu peristiwa pendidikan.

Setiap gerak perilaku yang disadari mengandung tujuan, yakni sasaran yang hendak dicapai melalui perialku tersebut. dalam kaitan pendidikan, tujuan dapat berarti objective, aim, atau purpose. Aim dan objective memiliki jangkauan makna yang lebih jauh dan luas yang penggunaannya mengacu kepada hasil-hasil pendidikan secara umum Mackenji (Suryana,2003).

Tujuan yang tampak dalam komunikasi antaranggota keluarga terutama antara orang tua dan anak di dalamnya terkandung nilai pendidikan. dari komunikasi tersebut terungkap bahwa tujuan pembinaan keluarga pada dasarnya tergantung kepada pandangan dasar yang diletakkan oleh orang tua dalam keluarga tersebut. hal ini dapat dipahami, karena tujuan apapun termasuk tujuan keluarga, tidak pernah terlepas dari tujuan hidup manusianya. Dalam lingkup keluarga, tujuan ditentukan oleh tujuan hidup 
orang tua dalam keluarga tersebut Soelaeman (2004), mempertegas dengan ungkapannya bahwa,"upaya dan langkah dalam mencapai tujuan hidup yang jelas garisnya itu". Langkah dan upaya pembinaan dasar-dasar nilai agama dalam keluarga tersebut, terlihat dalam setiap perilakunya, manifest, patokan, dan pandangan yang melandasi tujuan hidupnya, sehingga upaya serta tujuan pendidikan dan tujuan hidup keluarga dapat terbaca.

Tujuan orang tua selalu tersirat pada setiap gerak komunikasi yang terjadi. Tujuan tersebut ditemukan dalam ungkapan kata-kata atau gerak badaniah orang tua dengan anak-anaknya. Pada tahap yang sangat umum, tujuan pembinaan anak-anak dalam keluarga adalah mewujudkan anak yang shaleh, yaitu anak yang taat kepada Allah, orang tua, dan berakhlak yang baik di tengah masyarakat.

Taat kepada orang tua direalisasikan dalam bentuk pelaksanaan kewajibankewajiban yang diberikan orang tua kepada anak dalam berbagai jenis pembiasaan dan pembinaan tertentu. Orang tua menetapkan jenis-jenis pekerjaan harian yang merupakan bentuk operasional dari ketaatan kepada orang tua, seperti menyapu dan mengepel lantai rumah luar dalam setiap pagi, membereskan tempat tidur, menyalakan dan memadamkan lampu setiap hari. Dalam kegiatan harian ini terkandung makna tujuan, yaitu terciptanya sikap hidup disiplin terhadap waktu, dan tugas. Kewajiban tersebut ternyata tidak hanya sebatas meringankan beban kerja orang tua, tetapi juga mendidik anak untuk bersikap disiplin, mampu menggunakan waktu secara tepat dan menata hidup secara produktif dan bermanfaat.

Kewajiban memadamkan lampu menjelang terang atau mematikan kran WC pada saat tidak digunakan, mengandung tujuan agar anak memiliki sikap hemat dan efektif serta menjauhkan diri dari sikap boros dan mubazir. Membereskan tempat tidur setiap pagi, dan membuka jendela kamar tidur agar udara bersih, mengandung tujuan agar anak memiliki sikap disiplin dan cinta kerapihan serta menjauhkan diri dari sifat malas, menyapu dan mengepel lantai rumah luar dan dalam setiap hari, dan membereskan perkakas rumah, mengandung tujuan agar anak disiplin, dan cinta kebersihan dan kesehatan. Membina keluarga melaksanakan kewajiban kepada orang tua, adalah upaya memelihara dan meningkatkan disiplin pada diri anak, sehingga anak kelak akan mampu bertanggung jawab dan berdisiplin dalam segala permasalahan yang dihadapinya.

Tujuan orang tua dalam membina dasar-dasar nilai agama pada keluarga terungkap pula, yaitu agar anak-anak mampu berdoa. Doa berisi harapan, atau permintaan agar apa yang diidam-idamkan dapat tercapai atau memperoleh keberhasilan. Dalam kaitan ini, orang tua dan anak dalam keluarga merupakan kesatuan ikatan yang selalu mengharapkan keberhasilan seluruh anggota keluarga dalam menempuh cita-citanya.

Kesungguhan dan kekhusyukkan di saat berdoa mengandung arti yang sangat dalam. Doa menggambarkan perasaan kecil dan hina di hadapan pencipta. Ini berarti bahwa mengajar anak berdoa mengandung arti mendidik mereka untuk memahami 
keterbatasan diri, sehingga mereka mampu menjatuhkan dirinya dari sifat sombong dan takabur.

Kutipan di atas, dapat disimpulkan bahwa apabila orang tua sudah mengetahui pentingnya perhatian kepada anak dengan cara membimbing anak sesuai dengan cara yang telah Rasulullah ajarkan, maka orang tua hendaknya menempuh dengan mengembangkan fitrah anak sebagai upaya pembinaannya mulai dari keluarga sendiri. Sebab semua anak membutuhkan kasih sayang dan perhatian dari orang tuanya sendiri. Orang tua tidak boleh bersikap masa bodoh, karena semua ini akan berakibat kurang baik terhadap perilaku anak.

Dari uraian kelima indikator perhatian, dapat diambil kesimpulan bahwa orang tua yang tidak pernah atau kurang memperhatikan anak maka dapat mengakibatkan anak memiliki kepribadian yang kurang baik

Bimo Walgito (2003:15) mengemukakan psikologi merupakan ilmu tentang perilaku atau aktivitas-aktivitas individu (Branca, 1964; Morgan, dkk., 1984; Sartain, dkk., 1967; Woodworth dan Marquis, 1957). Perilaku atau aktivitas-aktivitas tersebut dalam pengertian yang luas, yaitu perilaku yang menampak (overt behavior) dan atau perilaku yang tidak menampak (innert behavior), demikian pula aktivitas-aktivitas tersebut di samping aktivitas motorik juga termasuk aktivitas tersebut di samping aktivitas emosional dan kognitif.

Wasty Soemanto (2003:183) mengemukakan perilaku dalam bahasa inggris merupakan daya gerak (gerakan) manusia secara biologis yang didasarkan pada system syaraf yang terdiri dari komposisi sel-sel yang disebut neuron. Apabila mendapat stimulasi, neuron akan melepaskan dorongan-dorongan elektronis yang merangsang neuron lainnya guna merangsang urat-urat, syaraf dan otot-otot tubuh.

Abin Syamsuddin Makmun (2007:23) mengemukakan berkenaan dengan pengertian atau konsep dasar perilaku ini terdapat beberapa aliran pandangan (paham), antara lain yang dikenal sebagai paham holism dan behaviorisme. Paham holistic menekankan bahwa perilaku itu bertujuan (purposive), yang berarti aspek interistik (niat, tekad, azam) dari dalam diri individu merupakan faktor penentu yang penting untuk melahirkan perilaku tertentu meskipun tanpa adanya perangsang (stimulus) yang datang dari lingkungan (naturalistic). Sedangkan pandangan behavioristik menekankan bahwa pola-pola perilaku itu dapat dibentuk melalui proses pembiasaan dan pengukuhan (reinforcement) dengan mengkondisikan stimulus (conditioning) dalam lingkungan (environmentalistik). Dengan demikian, perubahan perilaku (behavior change) sangat mungkin terjadi.

A. Wawan dan Dewi M, (2010:48) mengemukakan perilaku adalah respon individu terhadap suatu stimulus atau suatu tindakan yang dapat diamati dan mempunyai frekuensi sfesifik, durasi dan tujuan baik disadari maupun tidak. Perilaku merupakan kumpulan berbagai faktor yang saling berinteraksi. Sering tidak disadari bahwa interaksi tersebut amat kompleks sehingga kadang-kadang tidak sempat memikirkan penyebab seseorang menerapkan perilaku tertentu. Karena itu amat penting untuk dapat menelaah alasan dibalik perilaku individu, sebelum ia mampu mengubah perilaku tersebut. 
Sebagaimana diketahui perilaku atau aktivitas yang ada pada individu atau organisme itu tidak timbul dengan sendirinya, tetapi sebagai akibat dari stimulus yang diterima oleh organisme yang bersangkutan baik stimulus eksternal maupun stimulus internal. Namun demikian sebagian terbesar dari perilaku organisme itu sebagai respon terhadap stimulus eksternal. Bagaimana kaitan antara stimulus dan perilaku sebagai respon terdapat sudut pandang yang belum menyatu antara para ahli. Ada ahli yang memandang bahwa perilaku sebagai respon terhadap stimulus, akan sangat ditentukan oleh keadaan stimulusnya, dan individu atau organisme seakan-akan tidak mempunyai kemampuan untuk menentukan perilakunya, hubungan stimulus dan respon seakan-akan bersifat mekanistis. Pandangan semacam ini pada umumnya merupakan pandangan yang bersifat behavioristic.

Adapun penjelasan mengenai perilaku yang baik ini sebagai berikut:

a. Memberi salam kepada guru di sekolah ataupun di luar sekolah, yang berarti harus hormat setiap bertemu dengan guru di sekolah maupun ketika di lingkungan lainnya. Hal ini sangat penting karena sebagai siswa harus ta'dzim (hormat, menghargai) kepada orang yang mempunyai ilmu yaitu guru.

b. Menghormati kepada yang lebih tua dan menyayangi kepada yang lebih muda, hal ini dimaksudkan agar menghindari hubungan yang kurang baik di antara siswa di sekolah. Seperti siswa yang muda, harus hormat kepada kakak kelasnya, begitupun siswa yang menjadi kakak kelas, harus mempunyai rasa sayang dengan menjaga adik kelas dan memberikan perilaku yang baik dan patut dicontoh.

c. Kehadiran dalam kegiatan pembelajaran, hal ini harus diikuti oleh setiap siswa di sekolah. Dengan hadir dalam mengikuti pembelajaran di kelas, siswa akan senantiasa belajar, menambah ilmu pengetahuan, dan beraktivitas lainnya dengan bimbingan dari guru.

d. Berdoa ketika memulai aktivitas pembelajaran, harus dibiasakan setiap mengawali belajar di kelas. Dengan berdoa siswa akan menyadari bahwa hakikat ilmu datangnya dari Allah Swt, dan merasa membutuhkan ilmu sebagai bekal hidup. Maka dari itu, berdoa harus menjadi perilaku atau akhlak yang mendarah daging sehingga menjadi terbiasa dalam memulai setiap aktivitas apapun selain belajar.

e. Memakai pakaian rapi setiap hari, dimaksudkan agar siswa terdidik sejak dini dalam memakai pakaian yang sopan dan rapi.

f. Mengikuti kegiatan sekolah baik informal maupun ekstrakulikuler, tentunya kegiatan-kegiatan yang berhubungan dengan kegiatan di sekolah. dengan arahan guru, siswa harus mampu mengoptimalkan kemampuannya, bakat, seni, dan kepemimpinan di sekolah.

g. Ketepatan waktu mengikuti kegiatan pembelajaran, dimaksudkan siswa tepat waktu sesuai jam sekolah masuk, dan tidak terlambat datang ke sekolah. Hal ini untuk memupuk rasa disiplin sejak dini, agar ketika dewasa dalam beraktivitas siswa mampu mengelola waktu, dan membantu dalam keberhasilan siswa. 
h. Taat beribadah terutama salat lima waktu, siswa harus mempunyai jiwa keagamaan yang kuat sejak dini dan yang menjadi pembimbingnya, tentunya guru PAI yang memberikan pengajaran agama dan memberikan contoh yang baik bagi anak didiknya. Seperti jika melaksanakan salat berjamaah di sekolah, guru bukan hanya menyuruh siswa untuk salat, tetapi harus ikut melaksanakan salat berjamaah dengan siswa.

i. Saling menolong antar teman, di dalam sekolah siswa belajar bergaul, berkomunikasi dengan siswa lainnya, dan peka terhadap lingkungan di sekitarnya. Guru harus memberikan pemahaman terhadap siswa tentang etika hidup bersosial dan bermasyarakat. Seperti siswa ada yang sakit, harus dijenguknya, membantu temannya ketika kesulitan dalam belajar dan memberi bantuan ketika teman mendapat musibah serta menghiburnya.

j. Menjaga lingkungan sekolah, hal ini diartikan melatih siswa dalam menjaga kebersihan di sekolah maupun di lingkungan lainnya dan mencintai alam dengan menjaga dan merawatnya. Karena dengan sadar pemahaman "kebersihan itu sebagian dari iman", siswa belajar menjaga lingkungan, baik di kelas maupun di luar kelas. Seperti membuang sampah pada tempatnya, tidak mencoret-coret meja, tembok atau lainnya. Jika hal ini dibiasakan oleh siswa, maka dimanapun ia akan terbiasa menjaga lingkungan sekitarnya.

Apa yang telah dipaparkan menunjukkan perilaku itu muncul, perilaku muncul sebagai akibat adanya interaksi antara stimulus dan organisme. Bandura (2007:16) mengemukakan suatu formulasi mengenai perilaku, dan sekaligus dapat memberikan informasi bagaimana peran perilaku itu terhadap lingkungan dan terhadap individu atau organisme yang bersangkutan. Formulasi Bandura berwujud $\mathrm{B}=$ behavior, $\mathrm{E}=$ environment; $\mathrm{P}=$ person atau organisme. Dalam hal ini Bandura sendiri menggunakan pengertian person, bukan organisme. Perilaku, lingkungan, dan individu itu sendiri saling berinteraksi satu dengan yang lain. Ini berarti bahwa perilaku individu dapat mempengaruhi individu itu sendiri, di samping itu perilaku juga berpengaruh pada lingkungan, demikian pula lingkungan dapat mempengaruhi individu, demikian sebaliknya. Kalau orang bicara bahwa pemimpin itu adalah sebagai panutan, maka ini menyangkut hubungan antara perilaku pemimpin dengan lingkungannya, yaitu yang dipimpin, perilaku pemimpin dijadikan model bagi yang dipimpinnya. Kalau orang bicara bahwa orang perlu belajar dari pengalaman, ini menyangkut hubungan perilaku dengan diri individu yang bersangkutan. Apa yang telah diperbuat oleh seseorang akan dapat mempengaruhi orang itu sendiri.

Konsep manusia dan perilakunya dalam perspektif Islam, maka manusia terdiri dari unsur jasmani, ruhani dan nafsani yang menjadikan manusia sebagai makhluk yang sempurna di muka bumi. Manusia memiliki kebebasan dalam memilih perilaku yang baik dan yang buruk, yang benar atau yang salah, oleh karena itu manusia dibekali oleh akal dan hati. Unsur- unsur yang ada pada manusia membutuhkan tumbuh kembang yang sehat supaya bisa menjalankan fungsi manusia itu sendiri dimana dapat menjalankan tugas-tugas kemanusiaan dan peradabannya. Proses tumbuh kembang 
manusia akan dapat dicapai secara optimal melalui pendidikan yang dapat mengembangkan segala unsur dan potensi yang ada pada dirinya.

\section{HASIL PENELITIAN DAN PEMBAHASAN}

Pendidikan anak yang dilaksanakan di sekolah di bawah asuhan guru-guru, bukan berarti menjadi tanggung jawab pihak sekolah saja, melainkan keluarga juga masih memegang peranan penting dan tidak bisa terlepas dari tanggung jawab ini. Hal ini dapat dipahami karena sebagian besar waktu yang digunakan oleh anak berada dalam lingkungan keluarga. Untuk menumbuhkan serta membangkitkan kemampuan anak, orang tua perlu memberikan perhatian terhadap anak dalam pendidikan keagamaan di rumah.

Perilaku anak di sekolah dipengaruhi oleh dua faktor, yaitu faktor dari dalam individu itu sendiri dan faktor dari luar individu. Salah satu faktor dari luar individu yang dapat mempengaruhi terhadap perilaku anak adalah adanya perhatian dari orang tua terhadap pendidikan.

Perhatian merupakan reaksi umum dari organisme dan kesadaran yang menyebabkan bertambahnya aktivitas, daya konsentrasi dan pembatasan kesadaran terhadap sesuatu obyek Kartini Kartono (2010:111).

Perilaku anak tidak akan terbentuk dengan baik, apabila tidak ada perhatian. Seorang anak selain harus mempunyai perhatian yang tumbuh dari dirinya sendiri, anak juga memerlukan perhatian dari orang lain. Misalnya perhatian orang tua, anak sangat memerlukannya. Karena dengan adanya perhatian dari orang tua anak akan merasa lebih diperhatikan dan akan lebih berkualitas dalam perilakunya. dan sebaliknya apabila orang tua kurang bahkan tidak pernah sama sekali memperhatikan anak dalam pendidikan keagamaan di rumah, maka akan berakibat tidak baik terhadap perilaku anak di lingkungan sekolahnya. Dalam hal ini Tabroni Rusyan (2002:196) mengemukakan:

Perhatian orang tua merupakan faktor yang paling penting dalam membentuk perilaku anak. Kurangnya perhatian dapat menyebabkan anaknya tidak sopan, acuh tak acuh, dan Orang tua yang selalu sibuk dengan pekerjaan sehingga mengawasi dan membimbing anaknya dalam pendidikan keagamaan anak di rumah sangat kurang, dapat menyebabkan perilaku anak tidak terbentuk dengan baik.

Kutipan di atas, dapat disimpulkan bahwa apabila orang tidak memperhatikan pendidikan keagamaan di rumah, dan akibatnya pembentukan perilaku anak tidak akan membentuk perilaku yang baik.

Anak itu pandai tetapi dalam perilaku di lingkungan sekolah tidak baik karena kurangnya perhatian dan pengawasan, akhirnya perilaku anak berdampak ke hal tidak baik dan ini mengakibatkan anak tidak disukai oleh guru dan temannya. Mengenai masalah ini, Singgih D. Gunarsa mengemukakan:

Sebaiknya orang tua mengikuti dan mengamati dengan cermat perilaku anak, sehingga setiap perubahan penting baik positif maupun negative tidak lepas dari pengamatannya. Dengan demikian orang tua dapat memberi uluran tangan pada saat di mana bantuan dan nasehat orang tua diperlukan. Orang tua dapat memberikan dorongan 
mental dan gairah belajar bila anak sedang mengalami penurunan semangat belajar.(Singgih D. Gunarsa.,2004:100).

Jadi dengan adanya perhatian orang tua dalam pendidikan keagamaan anak di rumah orang tua dapat mengetahui perubahan anaknya dalam perilaku di lingkungan sekolah. Dengan adanya perhatian orang tua dapat bertindak cepat untuk memberikan bantuan dalam mengatasi kesulitan itu. Orang tua yang selalu memperhatikan dan mengikuti perkembangan anaknya dalam berperilaku, maka anak akan menganggap selalu diperhatikan oleh orang tuanya. Jadi dengan adanya perhatian tersebut, kesadaran anak untuk membentuk perilaku dengan baik dan membuat orang senang berteman dengannya.

Dengan demikian hubungan perhatian orang tua dalam pendidikan keagamaan anak di rumah dengan perilaku mereka di lingkungan sekolah tidak dapat dipisahkan, keduanya mempunyai hubungan yang erat.

Diinterpretasikan hubungan perhatian orang tua dalam pendidikan keagamaan anak di rumah, penulis telah mengumpulkan data melalui penyebaran angket dengan mengajukan pertanyaan sebanyak 52 item kepada 40 siswa dari kelas VII, VIII, IX SMP Muhammadiyah 10 Bandung.

Hubungan perhatian orang tua dalam pendidikan keagamaan anak di rumah, sebagai sampel penulis menyebarkan angket kepada siswa kelas VII, VIII, IX sebanyak 40 siswa. Angket yang digunakan dalam hal ini mencakup 5 indikator, yaitu: 1) Memberi contoh yang baik, 2) Pembiasaan, 3) Membuat suasana keagamaan di rumah, 4) Membimbing dengan bacaan-bacaan keagamaan, 5) Melibatkan anak dalam kegiatan keagamaan. Kemudian aspek-aspek tersebut penulis mengajukan 36 item soal angket. Analisis tersebut dilakukan dengan menggunakan pemanfaatan perhitunngan rata-rata, kemudian diinterpretasikan dengan menggunakan skala penilaian tersebut

Hasil penelitian menunjukan

Untuk mengetahui keseluruhan dari variabel $\mathrm{X}$ tersebut dapat disimpulkan bahwa nilai rata-rata perhatian orang tua dalam pendidikan keagamaan anak di rumah adalah $(4,8+4+4,1+4,5+4,5+3+4,3+4,8+4,6+4,6+4+3,9+3,8+4,3+3,8+$ $4,6+4,2+4,1+4+3,8+3,1+3,4+3,3+3,6+4+3,6+4,6+4,5+3,1+3,3+4,2$ $+4,3+4,5+4,2+3+4,2)=144,6: 36=4$. Nilai tersebut berada pada rentang 3,404,19 . Maka dapat diketahui bahwa perhatian orang tua dalam pendidikan keagamaan anak di rumah dengan kualifikasi tinggi.

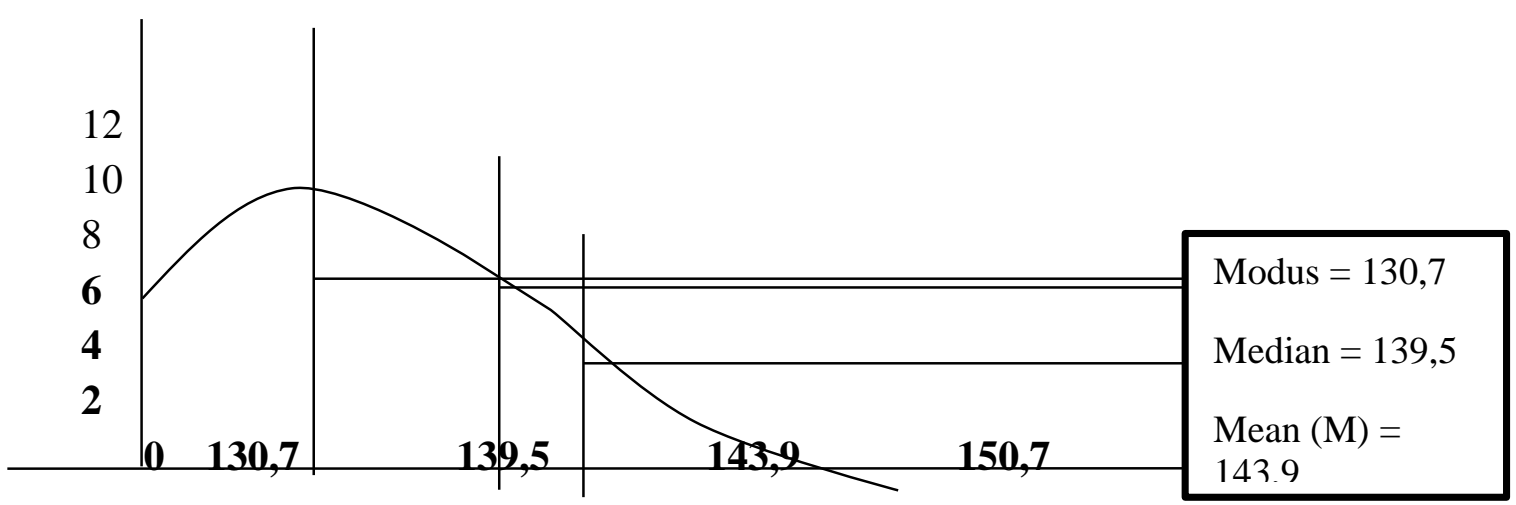


Hasil perhitungan diatas dapat disimpulkan bahwa data variabel X (perhatian orang tua dalam pendidikan keagamaan anak di rumah) berdistribusi normal karena diperoleh nilai Chi Kuadrat (X2) hitung sebesar 1,03 dan Chi Kuadrat (X2) tabel sebesar 2,97. Ternyata X2 hitung $(1,03)$ lebih besar dari X2 tabelnya $(2,97)$. Berdasarkan perhitungan di atas diketahui bahwa harga Mean $(\mathrm{M})=143,9$ harga Median $(\mathrm{Md})=$ 139,5, dan harga Modus $(\mathrm{Mo})=130,7$ hal ini berarti $\mathrm{M}>\mathrm{Md}>$ Mo.

Realitas perilaku mereka di lingkungan sekolah, sebagai sampel penulis menyebarkan angket kepada siswa kelas VII, VIII, IX sebanyak 40 siswa. Angket yang digunakan dalam hal ini mencakup 4 indikator, yaitu: 1) Akhlak terhadap Allah swt, 2) Akhlak terhadap diri sendiri, 3) Akhlak terhadap sesama manusia, 4) Akhlak terhadap lingkungan. Kemudian aspek-aspek tersebut penulis mengajukan 16 item soal angket.

Untuk mengetahui keseluruhan dari variabel $\mathrm{Y}$ tersebut dapat disimpulkan bahwa nilai rata-rata perilaku mereka di lingkungan sekolah $(4,7+3,4+4,2+4,4+4,5$ $+4+3,7+4,3+4,1+4,2+4,4+4,2+4+3,7+1,8+5,2)=64,8: 16=4$. Nilai berada pada rentang $3,40-4,19$, maka dapat diketahui bahwa perilaku mereka di lingkungan sekolah termasuk kualifikasi tinggi.

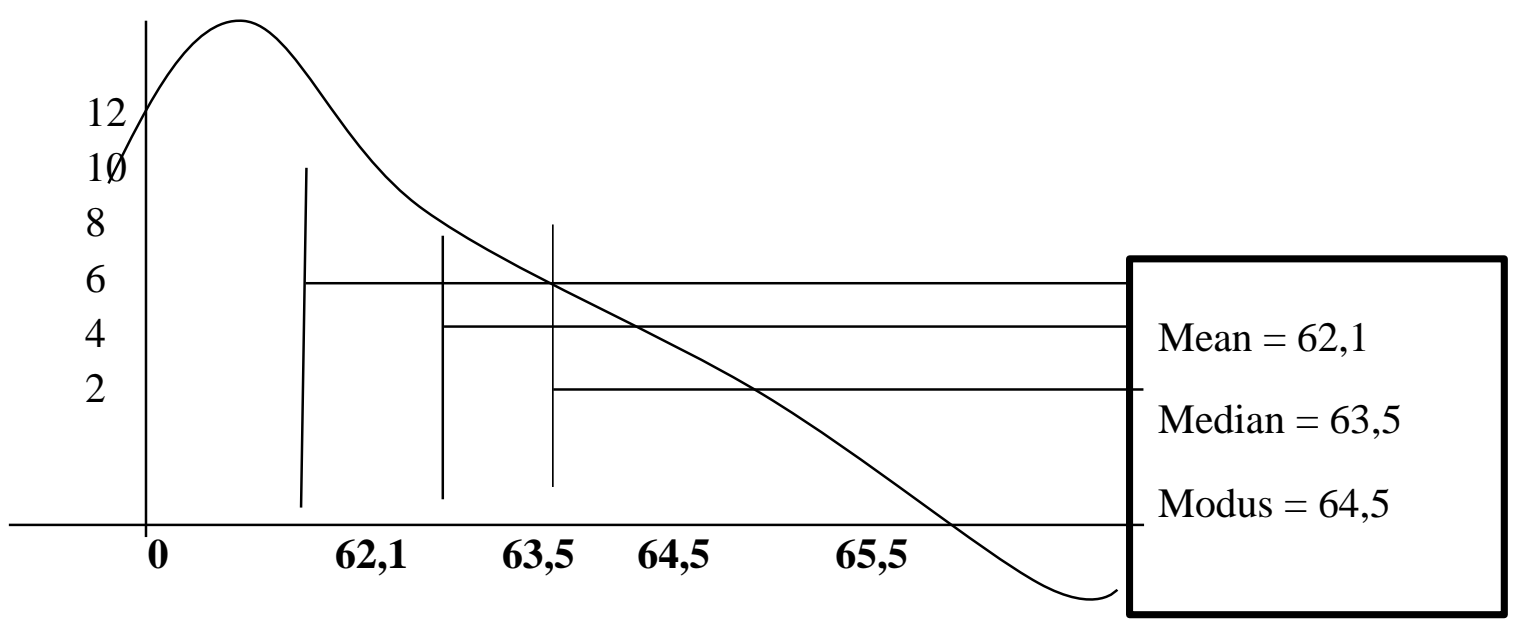

Berdasarkan hasil perhitungan diatas diperoleh nilai Chi Kuadrat (Y2) hitung sebesar 9,53 dan Chi Kuadrat (Y2) tabel sebesar 15,086. Ternyata Y2 hitung $(9,53)$ lebih besar dari Y2 tabelnya $(15,086)$. Maka dapat disimpulkan bahwa data variabel Y (perilaku mereka di lingkungan sekolah) berdistribusi normal. Berdasarkan perhitungan di atas diketahui bahwa harga Mean $(\mathrm{M})=62,1$ harga Median $(\mathrm{Md})=63,5$, dan harga Modus $(\mathrm{Mo})=64,5$ hal ini berarti $\mathrm{M}>\mathrm{Md}>\mathrm{Mo}$.

Langkah selanjutnya dalam penelitian ini akan mengukur ada atau tidak adanya keterkaitan antara perhatian orang tua dalam pendidikan keagamaan anak di rumah hubungannya dengan perilaku mereka di lingkungan sekolah di SMP Muhammadiyah 
10 Bandung. Dari hasil perhitungan uji normalitas terhadap data kedua variabel yang diteliti, keduanya berdistribusi normal, sedangkan untuk analisis korelasi diperlukan langkah-langkah sebagai berikut:

Analisis ini bertujuan untuk mengetahui bentuk hubungan antara perhatian orang tua dalam pendidikan keagamaan anak di rumah hubungannya dengan perilaku mereka di lingkungan sekolah di SMP Muhammadiyah 10Bandung. Dari hasil perhitungan terhadap pasangan variabel $\mathrm{X}$ dan variabel $\mathrm{Y}$ diperoleh $\mathrm{a}=205,03$ dan $\mathrm{b}=0, .67$, sehingga diperoleh persamaan linier regresinya adalah $\mathrm{Y}=205,03+0,67 \mathrm{X}$. Kemudian diperoleh harga $F_{\text {hitung }}=4500$ dan $F_{\text {tabel }}=9488$. Dengan demikian $F_{\text {hitung }}<F_{\text {tabel }}$ atau $4500<9488$, sehingga data tersebut beregresi linear.

Perhitungan koefisiensi korelasi diperoleh harga $r=0,60$. Nilai tersebut berada pada interval 0,40 - 0,60, sehingga masuk ke dalam kategori sangat tinggi. Jadi dapat disimpulkan bahwa antara perhatian orang tua dalam pendidikan keagamaan anak di rumah hubungannya dengan perilaku mereka di lingkungan sekolah berkolerasi sangat tinggi.

Hasil Uji Hipotesis, diketahui harga koefisien korelasi (r) sebesar 0,60, kemudian berdasarkan perhitungan uji hipotesis diperoleh harga $t_{\text {hitung }}$ sebesar 6,16. Dan diperoleh harga $t_{\text {tabel }}$ sebesar 7,35. Sehingga $t_{\text {hitung }}<t_{\text {tabel }}$ yaitu $6,16<7,35$. Dengan demikian Ha yang menyatakan terdapat hubungan yang signifikan antara pen perhatian orang tua dalam pendidikan keagamaan anak di rumah hubungannya dengan perilaku mereka di lingkungan sekolah diterima, sedangkan Ho yang menyatakan tidak adanya hubungan yang signifikan antara perhatian orang tua dalam pendidikan keagamaan anak di rumah hubungannya dengan perilaku mereka di lingkungan sekolah ditolak.

Dari hasil perhitungan, diketahui bahwa derajat perhatian orang tua dalam pendidikan keagamaan anak di rumah hubungannya dengan perilaku mereka di lingkungan sekolah 60\%, sedangkan 40\% lainnya dipengaruhi oleh faktor lain. Pengaruh oleh faktor lain (Faizi Pratama, 2007) mengemukakan seperti :

a. lingkungan kultural, kebiasaan dan tata cara pergaulan yang berbeda- beda, sehingga dapat mempengaruhi perilaku siswa.

b. Lingkungan sosial, lingkungan sosial lebih banyak mempengaruhi perilaku ialah orang tua dan keluarga siswa itu sendiri.

c. Kepribadian, kepribadian tiap orang berbeda-beda, ini dipengaruhi oleh sifatsifat yang ada pada diri orang tersebut. Namun dapat pula dipengaruhi oleh faktor eksternal luar dirinya.

d. Budaya luar atau asing, perkembangan globalisasi sangat pesat. Banyak budayabudaya luar yang masuk ke Indonesia. Siswa harus mampu mem-filter atau menyaring budaya tersebut, akan berpengaruh baik terhadapnya. Sebaliknya, jika siswa tidak mampu menyaringnya, maka akan berpengaruh terhadap sikap dan tingkah lakunya.

e. Pergaulan sehari-hari, pergaulan di sekolah maupun di luar sekolah akan mempengaruhi perilaku siswa. Jika bergaul dengan orang-orang yang bisa dikatakan tidak baik, maka perilaku siswa pun juga tidak baik. Dan sebaliknya, 
jika bergaul dengan orang-orang yang baik, maka perilaku siswa pun juga akan baik. Maka dari itu, pandai-pandailah dalam memilih teman.

\section{SIMPULAN}

Berdasarkan hasil penelitian dan pembahasan dapat dikemukakan simpulan sebagai berikut. Hasil penelitian perhatian orang tua dalam pendidikan keagamaan anak di rumah hubungannya dengan perilaku mereka di lingkungan sekolah di SMP Muhammadiyah 10 Bandung, maka dapat ditarik simpulan sebagai berikut:

1. Realitas perhatian orang tua dalam pendidikan keagamaan anak di rumah (variabel X) berkategori baik. Berdasarkan perhitungan keseluruhan nilai ratarata perindikator : point a) memberi contoh yang baik diperoleh hasil 4,3, point b) pembiasaan diperoleh hasil 4, point c) membuat suasana keagamaan di rumah diperoleh hasil 3,5, point d) membimbing dengan bacaan-bacaan keagamaan diperoleh hasil 3,8, point e) melibatkan anak dalam kegiatan keagamaan diperoleh hasil 4. keseluruhan nilai tersebut termasuk kategori baik karena berada pada rentang 3,40-4,19.

2. Realitas perilaku mereka di lingkungan sekolah (variabel Y) berkategori baik. Berdasarkan perhitungan keseluruhan nilai rata-rata perindikator : point a) akhlak terhadap Allah swt diperoleh hasil 4,2, point b) akhlak terhadap diri sendiri diperoleh hasil 4, point c) akhlak terhadap sesame manusia diperoleh hasil 2,3, point d) akhlak terhadap lingkungan diperoleh hasil4,2. Keseluruhan nilai tersebut termasuk kategori baik karena berada pada rentang 3,40-4,19.

3. Realitas hubungan perhatian orang tua dalam pendidikan keagamaan anak di rumah dengan perilaku mereka di lingkungan sekolah diperoleh nilai korelasi $(0,60)$. Nilai tersebut diinterpretasikan bahwa hubungan antara variabel $\mathrm{X}$ dan variabel $\mathrm{Y}$ termasuk kategori korelasi/hubungan sangat tinggi, karena nilai tersebut berada pada rentang 0,40-0,60. Berdasarkan uji hipotesis, diperoleh nilai thitung sebesar 6,16 dan ttabel sebesar 7,35 dengan taraf signifikansi 1\%, jadi t hitung lebih kecil dari t tabel atau thitung $(6,16)<{ }_{\text {ttabel }}(7,35)$. Dengan demikian hipotesis nol (Ho) yang menyatakan tidak ada hubungan yang positif antara perhatian orang tua dalam pendidikan keagamaan anak di rumah (variabel $\mathrm{X}$ ) dengan perilaku mereka di lingkungan sekolah (variabel Y) diterima dan hipotesis alternatif $(\mathrm{Ha})$ ditolak yang menyatakan adanya hubungan antara variabel $\mathrm{X}$ dan variabel $\mathrm{Y}$ yaitu sebesar $60 \%$. Hal ini berarti masih terdapat $40 \%$ faktor lain yang mempengaruhi perilaku siswa di lingkungan sekolah.

\section{SARAN}

Berdasarkan pada uraian simpulan di atas, maka perlu untuk mengungkapkan saran sebagai berikut:

1. Dari hasil analisis variable $X$ Perhatian orang tua dalam pendidikan keagamaan anak di rumah mencapai kualifikasi tinggi. Walaupun demikian, tetap diharapkan orang tua mampu memperhatikan perilaku anak di lingkungan sekolah dan masyarakat. Dalam memperhatikan anak, orang tua harus bisa 
memberikan contoh yang baik, membiasakan dengan perilaku yang baik, membuat suasana keagamaan di rumah, membimbing dengan bacaan-bacaan keagamaan dan melibatkan anak dalam kegiatan keagamaan. Maka dari itu sebaiknya perhatian orang tua dapat mempengaruhi lebih banyak anak untuk berperilaku yang baik sesuai dengan ajaran islam yaitu untuk memperbaiki akhlak seorang muslim.

2. Dari hasil analisis variable Y perilaku mereka di lingkungan sekolah pada point c akhlak terhadap sesama manusia ternyata rendah. Akan tetapi walaupun demikian perlu diupayakan agar orang tua dan pihak sekolah memperhatikan faktor-faktor yang dapat meningkatkan akhlak mereka terhadap sesama manusia.

3. Diketahui kadar hubungan perhatian orang tua dalam pendidikan keagamaan anak di rumah dengan perilaku mereka di lingkungan sekolah mencapai angka sebesar $60 \%$, sedangkan faktor lainnya yaitu 40\%, maka perlu diperhatikan faktor-faktor lain tersebut yang dapat mempengaruhi akhlak terhadap Allah, akhlak terhadap diri sendiri, akhlak terhadap sesama manusia dan akhlak terhadap lingkungan.

\section{DAFTAR PUSTAKA}

Arikunto, S. (2003). Dasar-dasar Evaluasi Pendidikan. Jakarta: PT.Bumi Aksara.

Ngalim, P. (2009). Ilmu Pendidikan Teoritis dan Praktis. Jakarta: PT. Remaja Rosda Karya.

Pakasi, S. (2001). Anak dan Perkembangannya. Jakarta: PT. Gramedia.

Sudjana. (2005). Metode Statistika. Bandung: PT. Tarsito.

Suryabrata, S. (2009). Psikologi Pendidikan. Jakarta: PT. Raja Grafindo.

Uhbiyati, A. A. (2003). Ilmu Pendidikan Islam. Bandung: Pustaka Setia.

Walgito Bimo. (2004). Pengantar Psikologi Umum. Yogyakarta: Andi Offset.

Sauri Sofyan. (2006). Membangun Komunikasi Dalam Keluarga. Bandung: PT Genesindo.

Sauri Sofyan. (2017). Kesantunan Berbahasa. Bandung: Royyan Press.

Kartono Kartini. (2010). Psikologi Umum. Jakarta: Kencana.

Helmawati. (2017).Pendidikan Karakter Sehari-hari. Bandung: PT. Remaja Rosdakarya. Mahmud, Abdul. (2004). Akhlak Mulia. Jakarta: Gema Insani.

Ngalim Purwanto. (2009). Ilmu Pendidikan Teoretis dan Praktis. Bandung: PT Remaja Rosda Karya.

Slameto. (2003). Belajar dan Faktor-faktor yang Mempengaruhinya. Jakarta: Rineka Cipta.

Usman, M.U. (2003). Upaya Optimalisasi Kegiatan Belajar Mengajar. Bandung: Remaja Rosdakarya.

Sudjana. (2003). Teknik Analisis Regresi dan Korelasi. Bandung: Tarsito.

Sugiyono.(2012). Statistika Untuk Penelitian. Bandung: Alfabeta.

Salahudin Anas. (2009). Bimbingan Dan Konseling. Bandung: CV.Pustaka Setia. 
Hidayat Rahmat. (2015). Muhammad saw The Super Parent. Jakarta: PT Prima untuk Semesta.

Lestari Sri. (2012). Psikologi Keluarga. Jakarta: Prenadamedia Group. Walgito Bimo. (2003). Psikologi Sosial. Yogyakarta: CV Andi Offset.

Abdurrahman Jamal. (2010). Islamic Parenting. Solo: Aqwam.

Wulansari Diane. (2017). Didiklah Anak sesuai Zamannya. Jakarta: PT Visimedia Pustaka.

Hayati Tuti. (2016). Pengantar Statistika Pendidikan. Bandung: CV Insan Mandiri.

Hasanah Aan. (2013). Pendidikan Karakter Berperspektif Islam. Bandung: Insan Komunika.

Bungin Burhan. (2011). Metodologi Penelitian Kuantitatif. Jakarta: Kencana.

Subana. 2000. Statistik Pendidikan. Pustaka Setia: Bandung.

Tafsir, Ahmad. 2001. Ilmu pendidikan dalam persfektif Islam. Bandung : PT. Remaja rosdakarya.

Suharsimi Arikunto. 2006. Prosedur Penelitian Suatu Pendekatan Praktik. Rineka Cipta: Jakarta.

Mahmud. 2011. Metode penelitian pendidikan. Bandung : Pustaka setia Asrori Muhammad, 2009. Psikologi Pembelajaran. Bandung : CV Wacana Prima

Aliya, I. (2012). Analisis Kenakalan Remaja dan Perhatian Orang Tua Terhadap Prestasi Belajar Siswa SMP Muhammadiyah 1 Surakarta (Studi Kasus pada Siswa Kelas VIII SMP Muhammdiyah 1 Surakarta). Jurnal Pendidikan, 5.

Bangun, D. (2008, April). Hubungan Persepsi Siswa Tentang Perhatian Orang Tua, Kelengkapan Fasilitas Belajar, Dan Penggunaan Waktu Belajar Di Rumah Dengan Prestasi Belajar Ekonomi. Jurnal Ekonomi dan Pendidikan, 5, 1.

Casdasari, M. (2004). Pengaruh Perhatian Orang Tua dan Minat Belajar Dengan Prestasi Belajar Siswa (Penelitian yang dikhususkan pada Prestasi Belajar Pilihan Program Ilmu Pengetahuan Alam kelas XI SMA PGRI 2 Kajen Kabupaten Pekalongan Tahun Pelajaran 2004/2005. Jurnal Pendidikan.

Mawarsih, S. E. (2013, Juni). Pengaruh Perhataian Orang Tua Dan Motivasi Belajar Terhadap Prestasi Belajar Siswa SMA NEGERI Jumapolo. JUPE UNS, vol.1, 1 s/d 13.

Nahlawi, A. A. (2007). Ushulut Tarbiyah Islamiyah Wa Asalibha Fi Al Baitiwa Al Madrasatiwa Al Mujtama. Jakarta: Gema Insani Press.

Nurrofiah, D. (2008). Pengaruh Persepsi Siswa Tentang Iklim Sekolah dan Perhatian Orang Tua Terhadap Prestasi Belajar Ekonomi Akutansi UNILA. Jurnal Ekonomi dan Pendidikan.

Qomariyah, S. N. (2015, Februari). Pengaruh Perhatian Orang Tua Terhadap Prestasi. Jurnal Keluarga, 10. 